\title{
DEVELOPING INTERACTIVE READING AND WRITING LEARNING MULTIMEDIA FOR “BAHASA INGGRIS” GRADE X OF SENIOR HIGH SCHOOL
}

\author{
Ratih Ayu Hapsari Nugraheni dan Joko Priyana \\ Linguistik Terapan, Pascasarjana UNY \\ ratihhapsari11@gmail.com
}

\begin{abstract}
The objectives of this study are: (1) to identify the needs of grade $\mathrm{X}$ students of senior high school in learning English using interactive learning multimedia and (2) to develop reading and writing interactive learning multimedia for "Bahasa Inggris" for grade X students of senior high school. This research and development study follows ADDIE design model proposed by Branch (2009). The steps were conducting needs analysis, syllabus writing, first product development, expert judgment, revision, tryout, and final product development. The data of needs analysis were obtained in two schools, they were SMA N 1 and 2 Temanggung while the try-out was only done in SMA N 1 Temanggung. The data were collected by using questionnaire and interview. The quantitative data were analyzed by using the descriptive statistics and the qualitative data were analyzed qualitatively. This study develops a three-chapter interactive learning multimedia for reading and writing which consists of five main menus, i.e. User Guide, Materials, Semester Review, About the Developer, and References. Each chapter has ten tasks organized into Warmer, Vocabulary Builder, Reading, Vocabulary Exercises, Text Structure, Grammar Review, Writing, and Reflection. The results of the try-out indicate that the interactive learning multimedia is good/appropriate as shown by the mean value ranging from 3.04 to 3.48 .
\end{abstract}

Keywords: senior high school, reading and writing, developing interactive learning multimedia.

\section{PENGEMBANGAN MULTIMEDIA PEMBELAJARAN INTERAKTIF UNTUK KETERAMPILAN MEMBACA DAN MENULIS DARI BUKU TEKS "BAHASA INGGRIS" KELAS X SEKOLAH MENENGAH ATAS}

\begin{abstract}
ABSTRAK
Penelitian ini bertujuan untuk: (1) mengidentifikasi kebutuhan belajar siswa kelas X SMA dalam belajar Bahasa Inggris menggunakan multimedia pembelajaran interaktif dan (2) mengembangkan multimedia pembelajaran interaktif untuk keterampilan membaca dan menulis dari buku teks "Bahasa Inggris" kelas X SMA. Penelitian dan pengembangan ini mengikuti model desain ADDIE oleh Branch (2009) yang dilaksanakan melalui beberapa tahap, yaitu analisis kebutuhan, penulisan silabus, pengembangan produk pertama, penilaian ahli, revisi, uji coba, dan pengembangan produk akhir. Pengambilan data untuk analisis kebutuhan dilakukan di dua sekolah, yaitu SMAN 1 dan 2 Temanggung sedangkan uji coba hanya dilaksanakan di SMA N 1 Temanggung. Pengambilan data dilakukan dengan menggunakan kuesioner dan interview. Data kuantitatif dianalisis dengan menggunakan statistik deskriptif dan data kualitatif dianalisis secara kualitatif. Penelitian ini mengembangkan multimedia pembelajaran interaktif yang terdiri dari 5 menu utama, yaitu User Guide, Materials, Semester Review, About the Developer, dan References. Terdapat 3 bab untuk materi dengan 10 task untuk masing-masing bab. Task-task tersebut dibagi dalam beberapa sub-bab: Warmer, Vocabulary Builder, Reading, Vocabulary Exercises, Text Structure, Grammar Review, Writing, dan Reflection. Hasil uji coba produk menunjukan bahwa multimedia pembelajaran interaktif baik/ tepat ditunjukkan dengan nilai rata-rata 3.04 hingga 3.48 .
\end{abstract}

Kata Kunci: sekolah menengah atas (SMA), keterampilan membaca dan menulis, pengembangan multimedia pembelajaran interaktif 


\section{BACKGROUND}

Information technology is as a part of human life today. Therefore, it is reasonable if the learners should also be literate in information technology in order to support them in facing the global era. In education, the teachers are expected to integrate Information Communication Technology (ICT) into teaching and learning process as a supporting medium. The rule of ICT integration is clearly stated in the Ministry Regulation No. 65/2013 as one of the educational principles in order to increase the efficiency and effectiveness of learning.

The facility of ICT, including computer laboratory, actually has already been owned by many schools. Even, it is very common now to see students bring and use their own laptops and gadgets. Unfortunately, there are still few of them who utilize this facility particularly to deliver or learn the materials. The utilization of computers and laptops are usually only for browsing, typing papers, and doing presentation. In term English lesson, the teachers sometimes take advantages of the computers. They commonly use them to play the recording for listening skills. Meanwhile, other skills including reading and writing are still rarely taught by using computers or other ICT tools.

From many kinds of learning materials, interactive learning multimedia is one of them which are able to integrate the ICT into the related subjects. It is because multimedia will require the presence of $\mathrm{PC}$ as the medium to deliver the materials. According to Mirsha \& Sharma (2005: 61), multimedia is multisensory which engages the senses of students. It is called as "multisensory" since it refers to a web-based interactive computer-mediated application that combines text, sound, image, audio, video and graphic. If all of those elements are applied optimally, it can be good for the students to improve their ability in the subjects taught and attract them more during the

The use of interactive learning multimedia can then be one of the efforts to motivate them to learn any subject, including English. It is due to the appearance of multimedia which tends to be more interesting and attractive than other conventional textbooks.
Mirsha \& Sharma (2005: 2) then defines the term multimedia as a kind of media which is related to the computer-based delivery. Reddi (2003) in Mishra \& Sharma (2005: 7) adds that multimedia is an integration of some elements of the media, like audio, video, graphics, text, animation and the others into one synergetic and symbiotic whole. Therefore, the results will be more beneficial for the users rather than when those elements are presented individually.

There are some benefits of using the interactive learning multimedia. Caincross \& Mannion (2001: 158) mention five benefits, they are related to 1 ) the blending of multiple media, 2) the delivery control, 3 ) the access route, 4) the individual preference, and 5) the interactivity. Meanwhile, Klimova (2013: 113114) adds that interactive learning multimedia tend to look more modern and fashionable than other conventional materials. Pun (2013: 29) also states that use of technology, including multimedia, give so many options in order to make the teaching and learning process more interesting. It is due to the ability of technology to attract the language learners. With the rapid development of science and technology, the use of multimedia creates more fascinating teaching trends recently, including English teaching.

Leow (2014: 107-108) found some important impacts of using interactive learning multimedia. The use of multimedia to deliver the content of materials is considered making the learning experiences more meaningful. It is because the students tend to have more choice when they become the center of learning environment. Besides, his finding of study shows that the multimedia use also plays important roles toward students' retention and learning outcomes. Another impact is related to the appropriateness of student-centred learning for the classroom with the multimedia as the media to deliver the materials. When it is compared with the conventional learning materials, it looks more engaging and motivating for the learners. Lastly, different from learning with a teacher or instructor, the students find that the use of multimedia make them feel more flexible and engaged.

Related to the implentation of 2013 curriculum, the Ministry of Education and 
Culture has provided a textbook entitled "Bahasa Inggris" to facilitate the teaching and learning process. As it is a kind of conventional textbook which is not utilized by the capability to integrate with ICT, the development of interactive learning multimedia was necessary.

The "Bahasa Inggris" book for second semester consists of 116 pages with 9 chapters entitled "Meeting My Idol", "Complimenting and Showing Care", "Keeping a Diary", "Talking about an Idol", Somebody I Admire", "Issumboshi", "Malin Kundang", "Interviewing the Wright Brothers", "Strong Wind", and "Learning through Songs", . The input texts provided are various including texts, dialogs, pictures, lists of vocabulary, and many others. The book also let students to do many kinds of activities, including singing songs and doing games. In term of the book's layout, it is quite engaging since the book is colored with many pictures.

However, especially for teaching listening and speaking, the teachers usually have already implemented the ICT integration. It is by using computers, $\mathrm{CD}$, and the others to record the materials. Since the implementation of ICT should also be conducted for other skills like reading and writing, a sort of interactive multimedia which covers those two skills will be needed to be designed.

As the multimedia is designed for reading and writing skills, the principles of reading and writing are also implemented particularly in term of developing the content. There are some micro-skills and macro-skills of reading used i.e. recognizing the communicative function of written texts, according to form and purpose and inferring context that is not explicit by using background knowledge (Brown, 2004: 187-188).

Meanwhile, for the writing, micro-skills and macro-skills applied are that the students must be able to appropriately accomplish the communicative functions of written texts according to the form and purpose and convey links and connections between events and communicate such relations as main idea, supporting idea, new information, given information, generalization, and exemplification (Brown, 2004: 221).
Then, because the focus of this research is developing learning multimedia for the first semester of grade X students particularly for reading and writing skills, the content competences and basic competencies which are only related to those two skills will be used.

The development of multimedia is not purely based on the textbook. There are some adaptations given which are based on the students needs. The process is namenly the needs analysis. There are two main aspects involved in the needs analysis. Those aspects are content aspects and media aspects. For gaining the information related to the content aspects, the theory of target needs and learning needs by Hutchinson and Waters (1987) and task components by Nunan (2004). Therefore there are some components included for the content aspects i.e. necessities, lacks, wants, goal, input, procedure, setting, teacher's roles, and learners' roles. Meanwhile, the media aspects dealt with the elements of multimedia, including text, pictures, animation, audio, video, and navigation (Stemler, 1997; Mishra \& Sharma, 2005; Vaughan, 2011).

\section{RESEARCH METHOD}

Since the goal of this study was to develop interactive learning materials for high school students, this study was classified as Research and Development (R \& D) category (Gall, Gall, \& Borg, 2003: 569). In this study, the products was three-unit interactive English learning multimedia of reading and writing for "Bahasa Inggris" textbook grade X, specifically in the form of Adobe Flash.

The research procedure implemented in this study was ADDIE (Analyze, Design, Develop, Implement, and Evaluate) model by Branch (2009).

There are three kinds of analysis, they are setting, needs, and materials analysis. The process of analyzing the needs was done in two classes from two schools; they are class X MIA 2 and X MIA 6 of SMA Negeri 1 Temanggung and class X MIA C of SMA Negeri 2 Temanggung by distributing questionnaire. There were some points asked in the questionnaire divided into content and media aspects. The points involved in the content aspects were related to the task 
components proposed by Nunan (2004: 53-174). Then, the questions for media aspects dealt with the elements of multimedia by Ivers \& Barron (2002), Mishra \& Sharma (2005), and Vaughan (2011).

The percentage of respondents were then determined and the data were classified as quantitative data. Afterwards, the data found were analyzed as the basis and guidance in developing the multimedia.

A syllabus as guideline in developing the materials has designed in this step. The syllabus design was based on textbook "Bahasa Inggris" which had been analyzed using the result of needs analysis. New materials as the content of interactive learning multimedia was also created based on the syllabus.

After creating the content, the layout of interactive learning multimedia was then designed by considering the result of the needs analysis (media aspects). Firstly, the flowchart was made to describe the flow, sequence, and linkage among the page slides in the multimedia. Next, the storyboard was created based on the flowchart and the materials.

Development

The interactive learning multimedia was developed using Adobe Flash CS6 software and some other supporting programs, including Picasa 3 Photo Editor, Photoscape Photo Editor, and Microsoft PowerPoint 2007. The result was namely the first draft.

The first draft which was completely done was passed through some examinations and validations by experts. There were two aspects which were examined and validated (content and media aspects) so that the experts were also distinguished into two; they were the expert for materials and the expert for multimedia design. The data of expert judgment were also obtained by distributing questionnaire.

Mainly, the questionnaire is used to evaluate the appropriateness of the first draft whether it is related to the content or media aspects. The content aspects evaluated were related to the task components by Nunan (2004) including the appropriateness of the goal, inputs, procedures, setting, and the roles. Then, the media aspects were associated with the appropriateness of the elements of multimedia i.e. background, text, pictures, audio, and also navigation.

The results of the questionnaire were used as the feedback to revise the multimedia before they were tried-out in the classroom. The result of first revision was namely the second draft.

\section{Implementation (Try-out)}

The next step was the implementation or the try-out. The students were asked to use the multimedia as the learning materials in the classroom and at home. Meanwhile, the try-out questionnaire was also distributed. The distribution of the questionnaires was mainly to find the data whether the multimedia was appropriate with the students' needs or not. There were also two students who were picked as the interviewees to gain the qualitative data.

\section{Evaluation}

The results of try-out questionnaires were used to evaluate the interactive learning multimedia, whether they were appropriate with the students' needs or not. As there were two kinds of data collection techniques used; they were by distributing questionnaire and intervieweing, the data were then also divided into two; they were quantitative and qualitative data.

The quantitative data were found by measuring the mean value. Then, In order to make the quantitative data easier to read, those data were converted into the interval of mean values on a scale of 1 to 4 using the range of score which had been found. The formula of the range of interval was based on Widoyoko (2013: 110) below.

$$
\mathrm{R}(i)=\frac{X h-X 1}{4}
$$

$\mathrm{R}$ means the interval range, $\mathrm{Xh}$ is the highest score, and $\mathrm{X} 1$ represents the lowest score. The number 4 was found by considering that the range only consisted of four points, they were four points for Strongly Agree (SA), three points for Agree (A), two points for Disagree (D) and one point for Strongly Disagree (SD). 
Meanwhile, to analyze the qualitative data, the interview was recorded and then transcribed to see the appropriateness of multimedia with the students' needs.

The results of try-out questionnaire and interview were used to revise the second draft. The revised second draft was namely the final draft in the form of a set of reading and writing interactive learning multimedia for the grade $\mathrm{X}$ students.

\section{FINDINGS AND DISCUSSION}

The research subjects were year X MIA II and VI students SMA Negeri 1 Temanggung and class X MIA C students SMA Negeri 2 Temanggung. The total number of students was 86,40 boys and 46 girls. Their ages ranged from 15 to 17 years old so that they could be classified as adolescents.

The results of needs analysis show that the students were interested in learning using interactive learning multimedia which has several characteristics. The inputs presented should not exactly the same with the textbook and they should be adapted based on the students' needs. Meanwhile, input texts in the form of paragrapf with 551-650 word length were more necessary.

There were some activities preferred by the students including finding specific and important information from the texts for reading activity, studying the paragraph structures of certain texts for writing activity, completing incomplete sentences with correct words for vocabulary activity, and changing the form of sentences from one grammar form to another for grammar activity. They also preferred multimedia with 10 to 15 tasks per chapter.

Mostly, the students expected to use the interactive learning multimedia to study individually at home. Therefore, the role of teacher was only as the facilitator and controroller, not the main user.

In terms of multimedia layout, the students preferred colorful background with cartoon pictures. Then, they also preferred Bubblegum Sanz and Candara as the type of font with small size (around 15-17). For the backsound, a kind of instrumental music with fast rhytmic was mostly chosen by students.
They also preferred if the multimedia provided sound effect when the buttons were touched or clicked.

The first draft of interactive learning multimedia was developed with several features. There are two main pages i.e. start page and home page. The start page consisted of the title and start button. By clicking the start button, the users could simply go to the home page. Next, the home page involved the title, a sound button, a close button, and some menu buttons. The sound button was used to turn on and mute the music background and the close button was to close the program. There were five menu buttons, they were namely User Guide, Materials, Semester Review, About the Developer, and References.

After the interactive learning multimedia had been designed, the next step was the expert judgment. There were three experts who verified the trustworthiness the multimedia. The first and second experts validated the content aspect while the third expert validated the multimedia aspect.

The experts who validated the content aspects were a lecturer of English study program in Yogyakarta State University and the English teacher of SMA Negeri 1 Temanggung. The data from content validation showed that almost all the aspects within the content of multimedia were in good category in which the two experts mostly agree with the statements offered.

Although the content of materials were good in general, there were still some revisions needed. The revisions were particularly in term of the diction which was considered less appropriate for the learning materials. The experts also suggested using clearer and more understandable sentences mainly for the instructions. If it was possible, the titles and sentences in Tujuan Pembelajaran pages should be in English and they should use words and sentences which were addressed to the students. Therefore, there were some parts from the content of materials which needed to be revised. The parts included the Start Page, Tujuan Pembelajaran and Task 2 of all chapters, and the tasks with key answer feedback.

For the media aspects, the validator was a lecturer of Electronics study program 
in Yogyakarta State University. In general, the reading and writing interactive learning multimedia developed were also quite good and able to be used as the learning media. It was proven by most of the items in the questionniare which were classified in good category. However, there were two points which were considered as poor. The expert assumed that the multimedia were not enough to help the students to understand the materials. Some notes were also given which were mainly about bugs (errors) found within the multimedia. The bugs were on Chapter 13 Task 3, Task 4, and Task 10, Chapter 14 Task 3 and Task 4, and Chapter 15 Task 3 and Task 4.

He also suggested that there should be notes in the last page of semester review dealt with the students' answers, whether their answers were right or wrong. In term of layout features, the expert suggested that the backsound volume should be able to set. Therefore, the sound could be hardened and softened.

There were some parts within the interactive learning multimedia which need to be revised based on the notes from the media expert. Mostly, the revision was related to the bugs occured, including for the Start Page and Task 3, Task 4, and Task 10 of all chapters.

The first draft was then revised based on the suggestions from the validators. The result of the revised draft was namely the second draft which was ready to be tried-out to the students.

The Try-out was conducted to 52 students of classes X MIA II and X MIA VI SMA Negeri 1 Temanggung starting from Saturday, April 11 to Monday, April 22, 2015. The procedure of the try out consisted of: 1) describing the interactive learning multimedia to the students, 2) distributing the CDs, 3) giving example how to operate the interactive learning multimedia, 4) distributing the try-out questionnaire, 5) asking students to use the interactive learning multimedia themselves, and 6) interviewing some of the students.

The data from try-out showed that the developed interactive learning multimedia was considered appropriate. The mean value for both content and media aspects were ranging from 3.04 to 3.48 , classified as good category.
For the content aspects especially in term of goals, the try-out data showed that the materials helped the students to study English particularly biographical recount and narrative texts. The materials also helped them to improve their reading and writing skills along with the vocabulary and grammar mastery.

Meanwhile, in term of inputs, the instructions and inputs for reading and grammar within the multimedia interactive were understandable and in line with the topics. The lengths of texts and the number of tasks were also appropriate. There was also a new vocabulary list on each chapter. Therefore, the students could simply enrich their vocabulary by learning through interactive learning multimedia.

Regarding the procedure, the activities in the materials helped the students to learn about English more, whether it was for reading, writing, vocabulary, or grammar. Then, the students also agreed that the activities provided were interesting and motivating. Therefore, the activities in the multimedia could be a solution of a problem commonly faced by the students, it is about motivation, as stated by Harmer (2001). The activities were already sequenced from the easiest to the most difficult for each chapter. Besides, the level of difficulties of the activities was also appropriate to students' proficiency. The students could use the interactive learning multimedia at home as the multimedia were already set for self-learning. It also means that the students could be more actively and independently in learning English particularly for reading and writing. Lastly, the contents of interactive learning multimedia were advantageous for students in their daily life. There were also some values contained in the materials in order to improve their attitude skills.

There were some media aspects evaluated regarding the interactive learning multimedia. The aspects that would be evaluated dealt with the screen design and the elements of multimedia.

The screen design including the multimedia background and colors were interesting based on students' opinion. In term of elements of multimedia, the fonts of text used 
were Bubblegum Sanz and Candara and they were also considered as interesting, appropriate and readable.

The students stated that the cartoon pictures applied within the multimedia were also interesting and appropriate with the topic. The music and tones applied were good to be listened to and they did not disturb them while completing the materials. The backsound music was also cheerful in order to avoid the students feeling bored or sleepy. In term of the navigation system, they did not find any difficulty in operating it. It was because the buttons were appropriate, easy to use, and they could work properly. The guidance presented in the multimedia was also clear and understandable. Therefore, the interactive learning multimedia could help and motivate students to learn the materials in general.

Furthermore, the appropriate interactive reading and writing learning multimedia have some features. There are two main pages i.e. Start page and Home page. Start page is a page which welcomes the users just after they open the multimedia program. Meanwhile, the Home page involved the title, a sound button, a close button, and some menu buttons. The menu buttons are for entering the menus provided. Those menus are User Guide, Materials, Semester Review, About the Developer, and References

User Guide page is where the guidance to operate the multimedia is displayed. Materials page consisted of three other menus which indicated to chapters that could be learnt by students. The menus namely Chapter 13 entitled "Somebody I Admire", Chapter 14 entitled "Issumboshi", and Chapter 15 entitled "Malin Kundang". The topic for Chapter 13 is about national heroes with biographical recount as the input texts. Then, Chapter 14 and Chapter 15 discusses the narrative texts (fairy tale amd legend).

Each chapter involved several activities for reading, writing, vocabulary, and grammar which were arranged in some sub-chapters. Those sub-chapters are Warmer, Vocabulary Builder, Reading, Vocabulary Exercises, Text Structure, Grammar Review, and Writing.
Warmer consists of one task which is for encouraging and giving description toward what the students will learn in the chapter. Next, Vocabulary Builder is the part for vocabulary introduction. Reading is the part of the reading tasks in the materials. Vocabulary Exercises is provided to let the students practice the vocabulary they have learnt before. Text Structure is the part where the students can learn about the structure of a text. Then, Grammar Review is where the explanation and exercises of the grammar are displayed. Lastly, Writing is the part of the writing tasks in the materials. The total number of task for each chapter is ten and the chapter is ended by Reflection.

The next main menu was Semester Review where the students could measure their own understanding through some multiple choice exercises. Then, About the Developer presents the short biodata of the developer. Lastly, References showed sources used to create the content of multimedia. The appearance of the title, buttons, and the pictures was also accompanied by sounds or tones.

\section{CONCLUSION}

The study was mainly aimed to develop an interactive reading and writing learning multimedia for grade $\mathrm{X}$ of senior high school based on "Bahasa Inggris" textbook. The research procedure used was ADDIE instructional design model proposed with five phases, they are Analyze, Design, Develop, Implement, and Evaluate. The results of this study show that the developed multimedia was appropriate with the students' needs. The materials (content) of multimedia is easy to understand and helpful for the students to study reading and writing. Meanwhile, the design is also interesting and the navigation is easy to operate without any error or bug found.

There are some recommendations for the next research and development of the English learning materials that are addressed to the material developers, the English teachers, and the students. For the material developers, they should attempt to develop such interesting and easy-to-operate learning multimedia. Considering the students' needs is also needed for the better results. Meanwhile, for the 
English teachers, they should be more creative in delivering the materials. If it is possible, they should also develop the learning media themselves. As an example is developing the interactive learning multimedia. Lastly, for the students, As there are so many kinds of learning media to be used for self-learning, including the interactive learning multimedia, they should be more diligent to study outside the classroom.

\section{REFERENCES}

Branch, R. M. 2009. Instructional Design: The ADDIE Approach. New York: Springer.

Brown, H. D. 2001. Teaching by Principles: an Interactive Approach to Language Pedagogy, 2nd Edition. New York: Pearson Education.

2004. Language Assessment: Principles and Classroom Practices. New York: Pearson Education.

Caincross, S. \& Mannion, M. 2001. Interactive Multimedia and Learning: Realizing the benefits. IETI Journal, 38, 2: 156-164.

Gall, Gall, M. D., \& Borg, W. R,. 2003. Educational Research: an Introduction (seventh edition). Boston: Pearson Education, Inc.

Hutchinson, T. \& Waters, A. 1987. English for Specific Purpose. Cambridge: Cambridge University Press.
Klimova, B. F. 2013. Multimedia in Teaching of Foreign Languages. Journal of language and cultural education, 1.1. 112-121.

Leow, F. 2014. Interactive Multimedia Learning: Innovating Classroom Education in a Malaysia University. TOJET: The Turkish online journal of educational technology - April 2014, volume 13 issue 2.

Mirsha, S. \& Sharma, R. C. 2005. Interactive Multimedia in Education and Training. London: Idea Group.

Nunan, D. 2004. Task-Based Language Teaching. Cambridge: Cambridge University Press.

Pun, M. 2013. The Use of Multimedia Technology in English Language Teaching: a Global Perspective. Crossing the border: international journal of interdisciplinary studies, 1 (1). 29-38.

Stemler, L. K. 1997. Educational Characteristics of Multimedia: a Literature Review. Journal of educational multimedia and hypermedia. 19976 (3/4), 339-359, Retrieved from pesona.mmu.edu.my.

Vaughan, T. 2011. Multimedia Making it Works. New York: Mc Graw-Hill.

Widoyoko, E. P. 2013. Teknik Penyusunan Instrumen Penelitian. Yogyakarta: Pustaka pelajar. 